\title{
Ayurveda Maintenance Therapy in Recurrent Ovarian Cancer
}

\author{
Pankaj Wanjarkhedkar ${ }^{10}$ Padmaj Kulkarni ${ }^{10}$ Sachin Hingmire ${ }^{1}$ Dhananjay Kelkar ${ }^{1}$ Kamlesh Bokil $^{2}$ \\ ${ }^{1}$ Department of Oncology - VLM Cancer Center; Deenanath \\ Mangeshkar Hospital \& Research Center, Pune, Maharashtra, India \\ 2 Dwidal Nursing Home, Pune, Maharashtra, India \\ Address for correspondence Pankaj Wanjarkhedkar, MD Ayurveda, \\ Department of Oncology - VLM Cancer Center; Deenanath \\ Mangeshkar Hospital \& Research Center, Pune, MH, India \\ (e-mail: drwpankaj@gmail.com).
}

Ind J Med Paediatr Oncol 2022;43:434-438.

\begin{abstract}
Keywords

- recurrent ovarian cancer

- progression-free survival

- platinum-free interval

- ayurveda maintenance treatment

- ZINCA-30

Despite optimal surgery and first-line platinum-based doublet chemotherapy, approximately 70 to $80 \%$ of patients with epithelial ovarian cancers relapse. Two cases of recurrent ovarian cancer (ROC) were treated with non-platinum-based Ayurveda maintenance therapy (AMT) consisting of drugs having a herbal and herbomineral origin. This regimen was followed over a period of 3 years and progression-free survival (PFS) was noted along with platinum-free interval (PFI). Two patients were diagnosed with $B R C A 1$ mutated recurrent high-grade serous ovarian carcinoma and treated with the per-oral AMT regimen labeled as ZINCA-30 in our hospital after completion of standard of care treatment and followed up until progression. The ZINCA-30 regimen comprising Jasada (traditional Zinc preparation), Indukanth kwatham and Curcuma amada powder in combination was prescribed based on Rasayana chikitsa postulated in Ayurveda. The patients were followed up every 3 months. The progression-free survival observed in these patients was 28 months and 45 months, respectively. These two pilot cases suggested an increased platinum-free interval (PFI), improved progression-free survival (PFS) in recurrent ovarian cancer (ROC), with the AMT labeled as ZINCA-30 after chemotherapy.
\end{abstract}

\section{Introduction}

Despite optimal surgery and first-line platinum-based doublet chemotherapy, approximately 70 to $80 \%$ of patients with epithelial ovarian cancers show a relapse. ${ }^{1}$ The most important features that influence the treatment choice in recurrent ovarian cancer (ROC) with respect to systemic therapy are tumor histology, BRCA mutation status, platinum-free interval (PFI), and previous treatment with an anti-VEGF monoclonal antibody. The presence of germline or somatic BRCA mutations allows platinum-responsive patients to optimize the chemotherapy efficacy and prolong progression-free survival (PFS) using a PARP inhibitor given as maintenance therapy until progression. ${ }^{1}$

Response to platinum re-treatment in recurrent epithelial ovarian cancer is related to PFI. The most preferred and accepted chemotherapy in the treatment of platinumsensitive ( $\mathrm{PFI}>6$ months) recurrence is platinum-based combination regimens. It is considered that extending the PFI with non-platinum agents may enhance the response and the outcome of subsequent re-challenge with platinum. $^{2}$

Therefore, the exploration for therapies with minimal toxicities to increase the PFS was initiated. Time to relapse
DOI https://doi.org/ 10.1055/s-0041-1740323. ISSN 0971-5851. (c) 2022. Indian Society of Medical and Paediatric Oncology. All rights reserved.

This is an open access article published by Thieme under the terms of the Creative Commons Attribution-NonDerivative-NonCommercial-License, permitting copying and reproduction so long as the original work is given appropriate credit. Contents may not be used for commercial purposes, or adapted, remixed, transformed or built upon. (https://creativecommons.org/ licenses/by-nc-nd/4.0/)

Thieme Medical and Scientific Publishers Pvt. Ltd., A-12, 2nd Floor, Sector 2, Noida-201301 UP, India 
is an important prognostic factor in ovarian cancer as subsequent chemoresponse is based on this time interval. ${ }^{3}$

In the doctrines of Ayurveda, the clinical stages and treatments for benign and malignant tumors have been discussed in detail. ${ }^{4}$

Rasayana chikitsa is one of the therapeutic segments of Ayurveda, which helps to improve immunity, consists of compounds having immune-stimulant, immune-modulator effects and hence they restore health. ${ }^{5}$ A regimen with drugs having anti-cancer properties and predominant Rasayana herbs and minerals has been described here for the management of ROC.

\section{Methodology}

We report the detailed course as elaborated in - Table 1 and the follow-up of Ayurveda maintenance treatment (AMT) labeled as ZINCA-30 in two cases of recurrent high-grade serous ovarian cancer in our institution. Two BRCA mutated patients (refer to - Table 1 for details) of ROC were offered AMT ZINCA-30. These patients after completing the standard chemotherapy were not willing for any conventional maintenance therapy and had opted for ZINCA-30.

The per-oral ZINCA-30 regimen prescribed for both the patients has standardized Jasad Bhasma (JB), Indukanth Kwatam (IK) tablets and powdered Amra-Haridra (AH) (Curcuma amada); daily dosage to be continued until the next recurrence. $I K$ tablets (the detailed composition is mentioned in -Supplementary Table S1) (3,600 mg/day) were prescribed 30 minutes before food, while the $J B$ (10 mg $/ \mathrm{kg} /$ day) and $A H(1,200 \mathrm{mg} /$ day) combination was advised to be taken after consuming food.

The treatment was started after the last chemotherapy cycle in both patients. These patients were followed up 3 monthly with clinical as well as laboratory evaluation including biochemistry, CA 125 , and sonological evaluation of the abdomen and pelvis.

Patient 1 (PSK) was on regular follow-up until November 2020 when she presented with mild pain in the abdomen. Her clinical examination was unremarkable and CA125 level was normal. A PET CT evaluation on 02/11/2020 showed nodal recurrence along the right iliac vein and a mesenteric node. Thus, she had a PFS of 28 months after three earlier recurrences as mentioned in - Table 1.

She was treated with six cycles of paclitaxel and carboplatin from $06 / 11 / 2020$ to $01 / 03 / 2021$ and is now in complete regression (CR) as reported in PET CT dated 03/04/2021.

Patient 2 (BSK) has had a PFS of 45 months and has shown no signs of relapse at the time of submitting the manuscript.

The CA-125 level was within normal range throughout the period of observation until the last follow-up in both the patients (-Supplementary Table S2). The mean \pm standard deviation (SD) value of CA-125 in $\mathrm{U} / \mathrm{mL}$ was $5.15 \pm 1.12$ in patient 1 -PSK and $7.72 \pm 1.61$ in patient 2 -BSK, over the total duration of follow-up.

All hematological and biochemical parameters including liver function tests and renal function tests were observed to be within the normal limit (-Supplementary Table S3).
There are no clinically noticed, pathology (laboratory) documented, or patient-reported adverse events or side effects with ZINCA-30 in both cases.

\section{Discussion}

Epithelial ovarian cancer (EOC) is the most fatal among recurring gynecological malignancies and around $75 \%$ of females with EOC are diagnosed at FIGO stage III or IV. ${ }^{6}$

The median PFI of 11.9 months (interquartile range [IQR]: 3.6-21.9) among 28 recurred patients with the median number of treatment lines 4 (IQR: $3-6$ ) and median of 2 (IQR: 2-3) platinum lines was observed in a retrospective study between 2004 and 2014 with at least 3 years follow-up among 40 BRCA mutation carriers (26 BRCA1 and 14 BRCA2) with a mean age of 54 years, all underwent cytoreduction surgery and received platinum chemotherapy. ${ }^{7}$

GOG-0218 (PFS 14.1 vs. 10.3, $p<0.001$ ) and ICON7 (PFS 19.8 vs. $17.4, p<0.001)$ trials suggested that the use of bevacizumab maintenance after standard chemotherapy prolongs median PFS in ROC patients. ${ }^{8}$

In the AGO-OVAR-16 trial, pazopanib maintenance therapy for 24 months after the completion of first-line platinumbased therapy improved PFS by 5.6 months compared with placebo. ${ }^{9}$ SOLO2 investigated olaparib maintenance after $\geq 2$ lines of chemotherapy for ovarian cancer patients with germline BRCA mutations. The study concluded that olaparib significantly improved PFS as compared with placebo (19.1 months vs. 5.5 months, $p<0.0001) .^{10}$

The maintenance treatment options are being explored in the ROC setting including targeted therapy with vascular endothelial growth factor (VEGF) inhibitors such as bevacizumab and tyrosine kinase inhibitors (TKI) such as pazopanib and nintedanib. ${ }^{11}$

Fatigue, hematological, and GI toxicities are the most commonly observed adverse events with PARPi therapy. ${ }^{12}$ GI tract symptoms such as nausea, vomiting, anemia, neutropenia, fatigue, and abdominal pain are reported as primary adverse effects. Rare but serious adverse events of developing acute myeloid leukemia (AML) have been reported with phase III study of olaparib. ${ }^{13}$

In the phase 3 AGO-OVAR 16 study, grade 3 or 4 AEs of hypertension (30.8\%), neutropenia (9.9\%), liver-related toxicity $(9.4 \%)$, diarrhea (8.2\%), fatigue (2.7\%), thrombocytopenia (2.5\%), and palmar-plantar erythrodysesthesia (1.9\%) were significantly higher in the pazopanib arm than with placebo, and the treatment-related discontinuation rate was also higher with pazopanib (33.3\% vs. $5.6 \%) .{ }^{14}$

It has been observed in two phase III clinical trials in newly diagnosed advanced-stage ovarian cancer GOG 218 and GOG 262, around $18 \%$ of EOC were associated with BRCA1 and BRCA2 mutations and differed in tumor biology and treatment response. ${ }^{15}$

The platinum-free interval is the most important predictive factor for a response to subsequent lines of chemotherapy. It is also the most important prognostic factor for PFS and overall survival (OS) in patients with ROC. A non-platinum regimen is generally preferred as the most appropriate 
Table 1 Details of cancer treatment

\begin{tabular}{|c|c|c|c|}
\hline & Event Chronology & Patient 1-PSK & Patient 2-BSK \\
\hline & Age in years & 50 & 48 \\
\hline & Co-morbidity & Hypothyroidism 10 years & No \\
\hline & Family history & Not significant & $\begin{array}{l}\text { Mother: ovarian cancer } \\
\text { Brother: non-Hodgkin lymphoma }\end{array}$ \\
\hline & $\begin{array}{l}\text { Cancer antigen } 125 \text { (CA 125) at } \\
\text { diagnosis }\end{array}$ & $158 \mathrm{U} / \mathrm{mL}$ & $2881 \mathrm{U} / \mathrm{mL}$ \\
\hline & Primary cytoreduction surgery & $\begin{array}{l}\text { Total abdominal } \\
\text { hysterectomy + bilateral salpingo- } \\
\text { oophorectomy + omentectomy on } \\
23 / 06 / 2010\end{array}$ & $\begin{array}{l}\text { Total abdominal hysterectomy }+ \\
\text { bilateral salpingo-oophorectomy } \\
+ \text { omentectomy on } 11 / 7 / 2015\end{array}$ \\
\hline & $\begin{array}{l}\text { Diagnosis-histopathology } \\
\text { report }\end{array}$ & $\begin{array}{l}\text { Bilateral high-grade serous } \\
\text { cyst-adenocarcinoma } \\
\text { FIGO stage III-B }\end{array}$ & $\begin{array}{l}\text { Bilateral grade III serous papillary } \\
\text { adenocarcinoma } \\
\text { FIGO stage III-B }\end{array}$ \\
\hline & $B R C A$ mutation & $\begin{array}{l}\text { Positive in intron } 16 \text { of the } B R C A 1 \text { gene } \\
\text { C. } 5074+1 G>A\end{array}$ & $\begin{array}{l}\text { Positive in exon } 2 \text { of the } B R C A 1 \\
\text { gene } \\
\text { p.Glu23ValfsTer17 }\end{array}$ \\
\hline \multirow[t]{7}{*}{$\begin{array}{l}\text { Previously received } \\
\text { cancer therapies }\end{array}$} & Chemotherapy 1st line & $\begin{array}{l}6 \text { cycles nanoparticle formulation of } \\
\text { paclitaxel + carboplatin, last } \\
\text { on } 21 / 12 / 2010\end{array}$ & $\begin{array}{l}6 \text { cycles of paclitaxel + carboplatin } \\
\text { last on } 29 / 11 / 2015\end{array}$ \\
\hline & Recurrence 1 & $\begin{array}{l}\text { 12/03/2013 } \\
\text { (PFS: } 26 \text { months) }\end{array}$ & $\begin{array}{l}\text { 25/07/2017 } \\
\text { (PFS: } 20 \text { months) }\end{array}$ \\
\hline & Chemotherapy 2nd line & $\begin{array}{l}6 \text { cycles of gemcitabine + carboplatin, } \\
\text { last on } 23 / 09 / 2013\end{array}$ & $\begin{array}{l}6 \text { cycles of pegylated liposomal } \\
\text { doxorubicin + carboplatin, last on } \\
21 / 02 / 2018\end{array}$ \\
\hline & Recurrence 2 & $\begin{array}{l}\text { 30/06/2016 } \\
\text { (PFS: } 33 \text { months) }\end{array}$ & - \\
\hline & Chemotherapy 3rd line & $\begin{array}{l}6 \text { cycles of doxorubicin + carboplatin, } \\
\text { last on } 19 / 10 / 2016\end{array}$ & - \\
\hline & Recurrence 3 & $\begin{array}{l}\text { 11/01/2018 } \\
\text { (PFS: } 15 \text { months) }\end{array}$ & - \\
\hline & $\begin{array}{l}\text { 2nd cytoreduction } \\
\text { surgery followed by } \\
\text { chemotherapy 4th line }\end{array}$ & $\begin{array}{l}6 \text { cycles of liposomal } \\
\text { doxorubicin + carboplatin until } \\
02 / 07 / 2018\end{array}$ & - \\
\hline $\begin{array}{l}\text { Ayurveda } \\
\text { maintenance } \\
\text { treatment ZINCA-30 }\end{array}$ & Progression-free survival (PFS) & $\begin{array}{l}\text { Started from } 02 / 07 / 2018 \text { to } 01 / 11 / \\
2020\end{array}$ & $\begin{array}{l}\text { Started from } 21 / 05 / 2018 \text { till the } \\
\text { date of latest follow up on } 19 / 11 / \\
2021\end{array}$ \\
\hline $\begin{array}{l}\text { Present } \\
\text { status }\end{array}$ & & $\begin{array}{l}\text { Recurrence } 02 / 11 / 2020 \\
\text { (PFS: } 28 \text { months) }\end{array}$ & $\begin{array}{l}\text { No recurrence until 19/11/2021 } \\
\text { (PFS } 45 \text { months and continued) }\end{array}$ \\
\hline
\end{tabular}

approach when the disease recurs early after the chemotherapy, and platinum-based chemotherapy is usually recommended if the platinum-free interval exceeds 12 months. ${ }^{16}$

The goals of therapy in ROC should be palliation of cancerrelated symptoms, maintenance of the quality of life, and extension of life. Hence, there is a significant impetus for research for focusing on newer maintenance treatments for ROC. ${ }^{17}$

Therefore, the option of ATM was explored with the effective role of Rasayana properties of the herbs and minerals in the ZINCA-30 regimen.

Rasayana drugs in Ayurveda are herbal/herbomineral preparations or individual herbs used to rejuvenate or attain the complete potential of an individual to prevent diseases and degenerative changes that lead to the disease. The probable mechanism may be immune-stimulation, quench- ing free radicals, enhancing cellular detoxification mechanisms, repairing damaged non-proliferating cells, inducing cell proliferation, and self-renewal of damaged proliferating tissues, and replenishing those by replacing damaged or mutated cells with fresh cells. ${ }^{18}$

A combination labeled as ZINCA-30 regimen comprising Jasad Bhasma (classical Ayurveda Zinc preparation), Indukanth Kwatham tablets and powdered Curcuma amada (Amra-Haridra), was prescribed considering safety and efficacy in cancer treatment as discussed here. The Jasad bhasma (JB) is a bioabsorbable Rasayana preparation from Rasashashtra ${ }^{19}$; the pharmaceutic treatise of Ayurveda. The safety and bioactivity studies of the JB are well studied and documented. ${ }^{20}$ It has the presence of macro-, micro-, and nano-particles ${ }^{21}$ in the final safe ${ }^{22}$ products 
manufactured as per the guidelines of Ayurvedic Formulary of India. ${ }^{23} \mathrm{JB}$ is a zinc-based preparation, which was also studied in resistant ovarian cancer using SKOV3 and ES2 ovarian cancer cell lines and showed potential as a secondline treatment. ${ }^{24}$ Amra Haridra (AH), as mentioned in Ayurvedic Pharmacopeia of India, ${ }^{25}$ commonly called as mango ginger and botanically known as Curcuma amada Roxb. is a medicinal species of turmeric known for its anticancer potential, including ovarian cancer. It works by targeting the nuclear factor- $\alpha \mathrm{B}$ (NF- $\alpha \mathrm{B})$ pathway in human ovarian cancer cell lines SKOV3ip1 and HeyA8. ${ }^{26,27}$ Indukant Kwatham (IK $)^{28-30}$ has therapeutic implications for the cases of intra-abdominal cysts, ovarian cysts, benign and malignant ovarian tumors termed as Raktaja-Gulma. ${ }^{31}$ Indukant Kwatham has immunomodulatory effects after chemotherapy and is used in the form of aqueous or lipid extract. ${ }^{32,33}$ These patients were punctual for treatment and follow-up over the 3 years and continued to appear for their scheduled followups. In these cases, the ZINCA-30 regimen was non-platinum based and the PFS observed was 28 months and 45 months. There were no reported or noted AEs during the entire period of treatment in these patients.

For the patients treated here, in whom the recurrence was observed after 28 months, the complete response (CR) was observed on PET CT at the end of platinum-based chemotherapy ( $\mathrm{PBC}$ ), which may be because of a significant increase in the platinum sensitivity. The complete response to the rechallenged platinum-based treatment after AMT ZINCA-30 may be a possible scope of further study.

Therefore, the AMT ZINCA-30, being a non-platinumbased regimen may have a potential role in maintenance treatment after SOC as well as to increase the PFI, which eventually may lead to better OS, without any AEs or events.

\section{Conclusion}

1. Ayurveda maintenance therapy, ZINCA-30 can be a potential lead as an alternative non-platinum-based treatment option for increasing PFS in ROC.

2. The observations in these preliminary cases indicated increased PFI with AMT, ZINCA-30 after standard chemotherapy in ROC.

\section{Limitations and Further Scope}

This communication is merely a preliminary outcome of continued clinical observations, and a well-planned formal study is needed to test this hypothesis further.

Assessing the quality of life with the Global QOL Score and affordability can be studied in addition to this.

\section{Conflict of Interest}

None declared.

\section{References:}

1 Pignata S, C Cecere S, Du Bois A, Harter P, Heitz F. Treatment of recurrent ovarian cancer. Ann Oncol 2017;28(Suppl 8):viii51, viii56
2 Chuang Y-T, Chang C-L. Extending platinum-free interval in partially platinum-sensitive recurrent ovarian cancer by a nonplatinum regimen: its possible clinical significance. Taiwan J Obstet Gynecol 2012;51(03):336-341

3 Soyama H, Takano M, Miyamoto M, et al. Factors favouring longterm survival following recurrence in ovarian cancer. Mol Clin Oncol 2017;7(01):42-46

4 Balachandran P, Govindarajan R. Cancer-an ayurvedic perspective. Pharmacol Res 2005;51(01):19-30

5 Doshi GM, Une HD, Shanbhag PP. Rasayans and non-rasayans herbs: future immunodrug - Targets. Pharmacogn Rev 2013;7 (14):92-96

6 Gupta S, Nag S, Aggarwal S, Rauthan A, Warrier N. Maintenance therapy for recurrent epithelial ovarian cancer: current therapies and future perspectives - a review. J Ovarian Res 2019;12(01): 103. Doi: 10.1186/s13048-019-0579-0

7 Jorge S, Swisher EM, Norquist BM, et al. Patterns and duration of primary and recurrent treatment in ovarian cancer patients with germline BRCA mutations. Gynecol Oncol Rep 2019; 29:113-117

8 Aravantinos G, Pectasides D. Bevacizumab in combination with chemotherapy for the treatment of advanced ovarian cancer: a systematic review. J Ovarian Res 2014;7:57

9 Du Bois A, Floquet A, Kim J, et al. Randomized, double-blind, phase III trial of pazopanib versus placebo in women who have not progressed after first-line chemotherapy for advanced epithelial ovarian, fallopian tube, or primary peritoneal cancer (AEOC): results of an international intergroup trial (AGO-OVAR16). J Clin Oncol 2013;31(Suppl 18):LBA5503-LBA5503

10 Pujade-Lauraine E, Ledermann JA, Selle F, et al; SOLO2/ENGOTOv21 investigators. Olaparib tablets as maintenance therapy in patients with platinum-sensitive, relapsed ovarian cancer and a BRCA1/2 mutation (SOLO2/ENGOT-Ov21): a double-blind, randomised, placebo-controlled, phase 3 trial. [published correction appears in Lancet Oncol. 2017 Sep;18(9):e510]Lancet Oncol 2017;18(09):1274-1284

11 Cortez AJ, Tudrej P, Kujawa KA, Lisowska KM. Advances in ovarian cancer therapy. Cancer Chemother Pharmacol 2018;81(01):17-38

12 Pothuri B, O'Cearbhaill R, Eskander R, Armstrong D. Frontline PARP inhibitor maintenance therapy in ovarian cancer: A Society of Gynecologic Oncology practice statement. Gynecol Oncol 2020; 159(01):8-12

13 Montemorano L, Lightfoot MD, Bixel K. Role of olaparib as maintenance treatment for ovarian cancer: the evidence to date. OncoTargets Ther 2019;12:11497-11506

14 DiSilvestro P, Alvarez Secord A. Maintenance treatment of recurrent ovarian cancer: is it ready for prime time? Cancer Treat Rev 2018;69:53-65

15 Norquist BM, Harrell MI, Brady MF, et al. Inherited mutations in women with ovarian carcinoma. JAMA Oncol 2016;2(04): 482-490

16 Tomao F, D'Incalci M, Biagioli E, Peccatori FA, Colombo N. Restoring platinum sensitivity in recurrent ovarian cancer by extending the platinum-free interval: myth or reality? Cancer $2017 ; 123$ (18):3450-3459

17 Jorge S, Swisher EM, Norquist BM, et al. Patterns and duration of primary and recurrent treatment in ovarian cancer patients with germline BRCA mutations. Gynecol Oncol Rep 2019;29:113-117

18 Vayalil PK, Kuttan G, Kuttan R. Rasayanas: evidence for the concept of prevention of diseases. Am J Chin Med 2002;30(01): $155-171$

19 Umrani RD, Paknikar KM. Jasada bhasma, a zinc-based ayurvedic preparation: contemporary evidence of antidiabetic activity inspires development of a nanomedicine. Evid Based Complement Alternat Med 2015;2015:193156

20 Chavare A, Chowdari P, Ghosh S, et al. Safety and bioactivity studies of Jasad Bhasma and its in-process intermediate in Swiss mice. J Ethnopharmacol 2017;197:73-86 
21 Pal D, Gurjar VK. (2017) Nanometals in Bhasma: ayurvedic medicine. In: Rai, Ph.D M., Shegokar, Ph.D R., eds. Metal Nanoparticles in Pharma. Springer, Cham. doi-org-443.webvpn.fjmu. edu.cn/10.1007/978-3-319-63790-7_17

22 Umrani RD, Paknikar KM. Ayurvedic medicine zinc bhasma: physicochemical evaluation, anti-diabetic activity and safety assessment. J Biomed Nanotechnol 2011;7(01):148-149

23 Department of AYUSH Ministry of Health \& Family Welfare. The Ayurvedic Formulary of India, Part I. 2nd ed The Controller of Publications New Delhi 2003:227, 239

24 Bastow M, Kriedt CL, Baldassare J, Shah M, Klein C. Zinc is a potential therapeutic for chemoresistant ovarian cancer. J Exp Ther Oncol 2011;9(03):175-181

25 Department of AYUSH Ministry of Health \& Family Welfare. The Ayurvedic Pharmacopeia of India, Part I, Vol V. The Controller of Publications New Delhi 2006:13-15

26 Ramachandran C, Lollett IV, Escalon E, Quirin KW, Melnick SJ. Anticancer potential and mechanism of action of mango ginger (Curcuma amada Roxb.) supercritical $\mathrm{CO}_{2}$ extract in human glioblastoma cells. J Evid Based Complementary Altern Med 2015;20(02):109-119

27 Lin YG, Kunnumakkara AB, Nair A, et al. Curcumin inhibits tumor growth and angiogenesis in ovarian carcinoma by targeting the nuclear factor-KB pathway. Clinical Cancer Research13(11):3423-3430
28 Pandey V, ed. Sahastrayog, Kashaya Prakaran, Chap. 1. Verse 171. CCRASNew Delhi1990:298

29 Savrikar SS, Ravishankar B. Bhaishajya Kalpanaa - the Ayurvedic pharmaceutics - an overview. Afr J Tradit Complement Altern Med 2010;7(03):174-184

30 Dongre S, Pande S. Need and approach of pharmaceutical standardization of Kwath Kalpana in present scenario-a critique. Int J Ayurveda Pharma Res 2016;4(03):57-60. Accessed November 26, 2021 at: https://ijapr.in/index.php/ijapr/ article/view/321

31 Mishra BR, Katre SP. Raktaja Gulma in correlation with modern science conditions. Journal of Ayurveda and Integrated Medical Sciences 2018;3(02):73-77

32 George SK, Rajesh R, Kumar S, Sulekha B, Balaram P. A polyherbal ayurvedic drug-Indukantha Ghritha as an adjuvant to cancer chemotherapy via immunomodulation. Immunobiology 2008; 213(08):641-649

33 Sruthi CV, Vendamirtham S, Sindhu Afrom the proceedings of Insight Ayurveda 2013, Coimbatore. 24th and 25th May 2013. PA02.20. A comparative study on the total phenolic content and antioxidant property of two Ayurvedic formulations-Indukantham gritham and Indukantham kashayam. Anc Sci Life 2013;32 (Suppl 2):S65. Doi: 10.4103/0257-7941.123886 